\title{
Seasonality of chrysophyte cyst and diatom assemblages in varved Lake Nautajärvi - implications for palaeolimnological studies
}

\author{
Sanna T. KORKONEN,${ }^{1 *}$ Antti E.K. OJALA,${ }^{2}$ Emilia KOSONEN,${ }^{3}$ Jan WECKSTRÖM ${ }^{1}$ \\ ${ }^{1}$ Department of Environmental Sciences, University of Helsinki, Viikinkaari 1, 00014 Helsinki; ${ }^{2}$ Geological Survey of Finland, \\ Betonimiehenkuja 4, 02151 Espoo; ${ }^{3}$ Department of Geosciences and Geography, University of Helsinki, Gustaf Hällströmin katu 2b, \\ 00014 Helsinki, Finland \\ *Corresponding author: sanna.korkonen@helsinki.fi
}

\begin{abstract}
Phytoplankton species composition is strongly affected by seasons, which should be taken into account in palaeolimnological studies. Although chrysophyte cysts and diatoms are widely used as palaeobioindicators in palaeolimnological studies, only recently have attempts been made to use their modern deposition from sediment trap data to provide more detailed, seasonal-based environmental reconstructions. In this study sediment traps were used to record seasonality of chrysophyte cysts and diatoms during two climatically different years 2009 and 2010 in an annually laminated Lake Nautajärvi, Finland, and this seasonal data was then compared with the fossil record derived from the surface sediment of the lake. The overall changes in cyst and diatom assemblages between years and seasons are subtle. For both groups, no clear connection to any particular season could be detected in the sediment surface. Despite the climatological differences between the study years, the inter-annual accumulation rates of both algal groups were surprisingly similar, whereas the intra-annual accumulation rates differed substantially. This and the high amount of taxa occurring during all seasons in the trap samples implies that primary producers are more dependent on prevailing seasonal limnological conditions than on rapid, shortly lived episodes. Redundancy analysis (RDA) revealed that chrysophyte cyst assemblages from the spring sediment trap are mainly controlled by the spring discharge intensity, a surrogate variable of spring weather conditions, whereas precipitation and air temperature have the strongest impact on the summer assemblages. However, only discharge explains statistically significantly the variance in the cyst data. Precipitation and air temperature have the strongest impact on the diatom summer samples, whereas the spring sediment trap sample of the snowy and harsh winter of 2010 was strongly correlated with the spring discharge. However, none of the measured environmental variables explains the variance in the diatom data statistically significantly. The similarity between the algae found in the sediment traps and surface sediment sample suggests that within small and shallow lakes without any extreme environmental settings the surface sediment sample represents well the lake's overall algal composition and can thus be used in palaeolimnological studies.
\end{abstract}

Key words: Chrysophyte cyst; diatom; Finland; lake sediment; seasonality; sediment trap.

Received: March 2016. Accepted: December 2016.

\section{INTRODUCTION}

Seasonality of environmental variables have a strong effect on phytoplankton species composition and biomass especially in high latitude regions where lakes are ice covered during winter months. In high latitude lakes plankton succession starts at the time of ice break up either from cells or individuals that survived the winter or from primary colonization (Lampert and Sommer, 1997). The most common algal species in spring bloom at high latitude lakes usually belong to Diatomaphyceae, Chrysophyceae/Synurophyceae or Dinophyceae classes, which are tolerant of cooler water temperatures (Wetzel, 2001). During summer months, the epilimnion and the cooler and often more nutrient rich waters of the hypolimnion are separated by a thermocline in e.g. deep and humic lakes and the occurrences of algae usually decreases after the spring maximum (Wetzel, 2001). During autumnal overturn phytoplankton biomass increases as nutrients 'trapped' in the hypolimnion are brought to the epilimnion resulting in an autumnal bloom (Rautio et al., 2000). Small numbers of phytoplankton cells survive during winter season in the water column, attached to the bottom of the ice, or as resting cells in the bottom sediment (Salmi and Salonen, 2016).

Chrysophytes are mainly freshwater unicellular organisms occurring as solitary cells or colonial forms. Chrysophytes usually prefer cold, oligotrophic waters (Sandgren et al., 1995), but they can be found in a variety of environments (Siver, 1995). In oligotrophic dimictic lakes chrysophytes can compose $25-75 \%$ of the total phytoplankton biomass while in mesotrophic and eutrophic dimictic lakes the amount is considerably lower varying between 5 and 25\% (Sandgren, 1988). All chrysophytes produce siliceous resting stages, stomatocysts or simply cysts, as part of their life-cycle to ensure the survival of the chrysophyte population under unfavourable condi- 
tions. Cyst morphology is considered to be species-specific (Sandgren, 1983). Quantitative studies using chrysophyte cysts from sediment traps and surface sediments have shown that these organisms respond to changes in e.g., $\mathrm{pH}$ (Rybak et al., 1991; Facher and Schmidt, 1996), salinity (Pla and Anderson, 2005) and temperature (Kamenik and Schmidt, 2005; Pla-Rabes and Catalan, 2011; Hernandez-Almeida et al., 2015; de Jong et al., 2016).

Diatoms (Bacillariophyta) are siliceous microscopic algae, which are abundant world-wide where sufficient amounts of light and moisture are available for photosynthesis. Their distribution is controlled by a number of physico-chemical variables (temperature, $\mathrm{pH}$, salinity, nutrients) and due to their short life cycle they respond quickly to changes in their environment (Dixit et al., 1992). Moreover, diatoms are abundant and generally well preserved in sediments, they can be identified even to sub-species level, and usually have rather narrow ecological tolerances and optima (Dixit et al., 1992).

Chrysophytes and diatoms are often the most dominant algal groups in cool, high latitude oligotrophic lakes and ponds in the northern hemisphere (Moore, 1978; Elo-

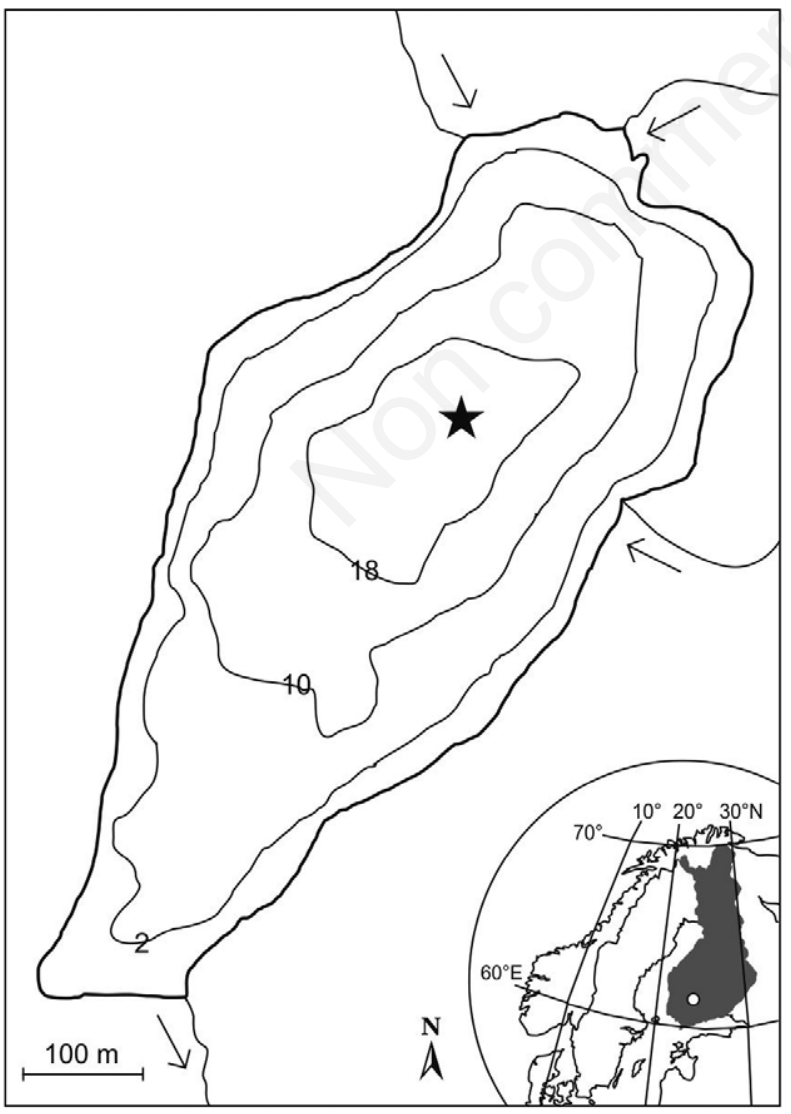

Fig. 1. Lake Nautajärvi and its location. The sediment trap and the surface sample are indicated by a star. ranta, 1986; Forsström et al., 2009). During the last century chrysophyte cysts and diatoms have been linked to a variety of environmental variables (see above; Duff et al., 1995; Juggins, 2013), but only recently modern sediment trap data of phytoplankton remains have been combined with a sediment core record of the same lake in order to provide more detailed, seasonal climate reconstructions (Lotter and Bigler, 2000; Köster and Pienitz, 2006; Hausmann and Pienitz, 2007; Pla and Catalan, 2011; Maier et al., 2013; de Jong et al., 2016). These studies have highlighted the need for more detailed information on species (especially chrysophytes) seasonality and taphonomy in palaeolimnological research. Sediment traps allow accurate calibration between seasonal and annual environmental variables and biological proxies, while surface sediments are usually representing several years of accumulated material thus missing the seasonal resolution.

The aim of this study is i) to investigate the seasonal variability of chrysophyte cysts and diatoms deposited in sediment traps in an annually laminated boreal lake Nautajärvi, Finland; ii) to compare the impact of two weatherwise and hydrologically different types of years on the chrysophyte and diatom assemblages; and iii) to compare assemblage composition of the seasonally trapped material with the assemblages of surface sediment samples.

\section{METHODS}

\section{Study site}

Lake Nautajärvi is a small (17 ha) oval-shaped lake with a maximum depth of $20 \mathrm{~m}$, located in central southern Finland $\left(61^{\circ} 48^{\prime} \mathrm{N}, 24^{\circ} 41^{\prime} \mathrm{E}\right)$ at $104 \mathrm{~m}$ asl (Fig. 1). Lake Nautajärvi is dimictic, dystrophic (Secchi depth < $2 \mathrm{~m}$ ) and slightly acidic with a $\mathrm{pH}$ of 5.8-6.0 (January 1989, January 1997; OIVA, 2015). The lake is mesotrophic with total nitrogen $(\mathrm{N})$ varying between $<440$ (epilimnion) and 800 (hypolimnion) $\mu \mathrm{g} \mathrm{L}^{-1}$ and total phosphorus (P) varying between 16-30 (epilimnion), and 48$84 \mu \mathrm{g} \mathrm{L}^{-1}$ (hypolimnion) (January 1989, January 1997; OIVA, 2015). Three inflows are located in the northern part of the lake and one outflow in the southern part. The lake's catchment area consists of boreal forest, mainly pine (Pinus sylvestris) and spruce (Picea abies), and agricultural land. The bedrock consists of deeply eroded coarse-grained granites partly overlain by till or a mixture of till and silt (Kujansuu et al., 1981). The sediment in the deepest part of Lake Nautajärvi contains clastic-biogenic type varves (Ojala, 2001; Ojala et al., 2013). Climate around the area is continental, July usually being the warmest month (mean temperature 15 to $18^{\circ} \mathrm{C}$ ) and January or February the coldest $\left(-5\right.$ to $\left.-12^{\circ} \mathrm{C}\right)$ (Finnish Meteorological Institute, 2012). The lake is ice covered usually from mid-December to early May (OIVA, 2015). As no 
monitored ice-break up and freezing days are available for Nautajärvi we obtained values for comparison from the closest lake that is monitored regularly by the Finnish Environment Institute. The ice-free period in Lake Kukkia (surface area of $43 \mathrm{~km}^{2}$; situates ca. $50 \mathrm{~km}$ south of Nautajärvi) lasted in 2009 from 30 April to 14 November and in 2010 from 27 April to 22 November (OIVA, 2015). Thus, no meaningful differences in ice-free period occurred between these years. Spring mixing occurs usually during May, summer stratification between May and October and autumnal mixing in October. Thus, the time periods of the seasonal sediment traps (Tab. 1) correspond well with the major seasonal changes in the lake. Weather during years 2009 and 2010, when the sediment traps were in operation, differed considerably; winter of 2009 was relatively mild while 2010 was a year of strong seasonal contrast with a harsh winter and heavy snowfall followed by a hot and dry summer (Finnish Meteorological Institute, 2012; Ojala et al., 2013).

\section{Environmental variables}

Three environmental variables (air temperature, precipitation and discharge; Tab. 1) were used in the study by Ojala et al. (2013) in order to assess their impact on annually laminated varve formation in Lake Nautajärvi. The same variables were expected to have a strong impact on species composition determined for the trapping periods of the two consecutive years. Mean seasonal air temperature and mean seasonal precipitation values are based on daily averages and were derived from Hyytiälä Forestry Field Station, located ca. $20 \mathrm{~km} \mathrm{NW/W} \mathrm{from}$ Lake Nautajärvi. The mean seasonal discharge information is based on measurements from Lake Äväntäjärvi, which is located $6 \mathrm{~km}$ south of Lake Nautajärvi and belongs to the same drainage system (OIVA, 2015). The mean seasonal temperature, precipitation and discharge values are calculated from daily averages of the sediment trapping periods.

\section{Sediment traps}

Near-bottom sediment traps were installed in the deepest, flat-bottomed basin in the middle of the lake in January 2009 (Fig. 1). The near-bottom sedimentary traps had either 2 tubes or 4 tubes with the inner diameter and length of all cylindrical sampling tubes of 104 and 700 $\mathrm{mm}$, respectively. Traps were emptied four times a year during the two years-long monitoring period (Tab. 1) to record the seasonal changes in accumulation and species composition of biological assemblages. However, as the seasonal periods for the sediment traps were not identical during the two years, some overlap between the seasons might have taken place. For a more detailed description of the sediment traps and their set-up see Ojala et al. (2013). The single deposition basin is proved to effectively trap most of the sedimented allochthonous and autochthonous matter (Ojala and Alenius, 2005).

\section{Surface sediment}

The surface sediment sample, comprising the topmost $1 \mathrm{~cm}$, was derived from the deepest part of the lake (Fig. 1) in spring 2010 using a piston gravity corer (Putkinen and Saarelainen, 1998). The surface sample was placed in a Minigrip plastic bag and stored in the dark at $4^{\circ} \mathrm{C}$ until analysis.

\section{Chrysophycean cyst and diatom analysis}

Chrysophyte cyst and diatom samples from sediment traps and surface sediment were prepared using the standard treatment for diatoms (Battarbee, 1986; Weckström et al., 1997). For chrysophyte cyst analysis the aliquot suspensions were dried on stubs for scanning electron microscope (SEM) work. A minimum of 200 chrysophyte cysts were counted and identified from SEM (Hitachi S4800) images. Some problematic cysts were grouped for analysing purposes. The cyst identification followed Duff et al. (1995), Facher and Schmidt (1996), Wilkinson et al.

Tab. 1. Dates for the sediment trap periods and seasonal environmental data (average of daily means for the trap periods).

\begin{tabular}{lcccc} 
& Trap monitoring period & $\begin{array}{c}\text { Discharge } \\
\left(\mathrm{m}^{-3} \mathrm{~s}^{-1}\right)\end{array}$ & $\begin{array}{c}\text { Precipitation } \\
(\mathrm{mm})\end{array}$ & $\begin{array}{c}\text { Temperature } \\
\left({ }^{\circ} \mathrm{C}\right)\end{array}$ \\
\hline Spring 2009 & $9.3-28.5 .2009$ & 0.68 & 68.4 & 3.64 \\
\hline Summer 2009 & $28.5-8.9 .2009$ & 0.30 & 13.6 & 14.20 \\
\hline Autumn 2009 & $8.9-14.1 .2010$ & 0.33 & 93.2 & -1.26 \\
\hline Winter 2009 & $14.11-25.3 .2010$ & 0.23 & 121.7 & -9.5 \\
\hline Spring 2010 & $25.3-24.5 .2010$ & 1.91 & 272.8 & 6.25 \\
\hline Summer 2010 & $24.5-15.9 .2010$ & 0.39 & 127 & 15.2 \\
\hline Autumn 2010 & $15.9-17.11 .2010$ & 0.42 & 161 & 3.8 \\
\hline Winter 2010 & $17.11-3.4 .2011$ & 0.25 & -9.0 \\
\hline
\end{tabular}


(2001), Pla (2001), Kamenik et al. (2005), and Baumann et al. (2010). Unidentified cysts, mainly the ones where the pore was not visible, were classified using probabilistic counting, i.e. the cysts were classified as a specific morphotype based on the percentage distribution of different morphotypes in a sample. For diatom analysis, the samples were mounted on microscope slides using Naphrax ${ }^{\circledR}$. A minimum of 300 diatoms were counted and identified along random transects at 1000x magnification. Diatom identification was based mainly on Krammer and Lange-Bertalot (1986, 1988, 1991a, 1991b).

DVB (divinylbenzene) microscopic markers were also counted to determine chrysophyte cyst and diatom accumulation rates from the sediment trap samples (Battarbee and Kneen, 1982).

\section{Numerical analysis}

Changes in chrysophyte cyst and diatom species rich- ness between different seasons and between two different years were analysed by comparing the number of taxa using rarefaction analysis (Figs. 2a and 3a; Birks and Line, 1992) with the program PAST 2.17b (Hammer et al., 2001). Rarefaction analysis produces realistic estimates of species richness without any bias associated with the variability of individual sample count size. Species abundance diagrams (Figs. 2a and 3a) were created using the program C2 (ver. 1.7.2.; Juggins, 2007). In order to simplify the abundance diagrams only most common taxa that had a relative abundance $>3 \%$ in any sample where included in Figs. 2a and 3a. Detrended correspondence analysis (DCA; Hill and Gauch, 1980), with detrending by segments and non-linear rescaling of axes, was used in order to explore the principal patterns of compositional variation along the first few DCA axes. As the DCA implied a linear relationship (2.1 SD for both groups) between the response and explanatory variables, principal components analysis (PCA) was used to summarize the major patterns of variation within the
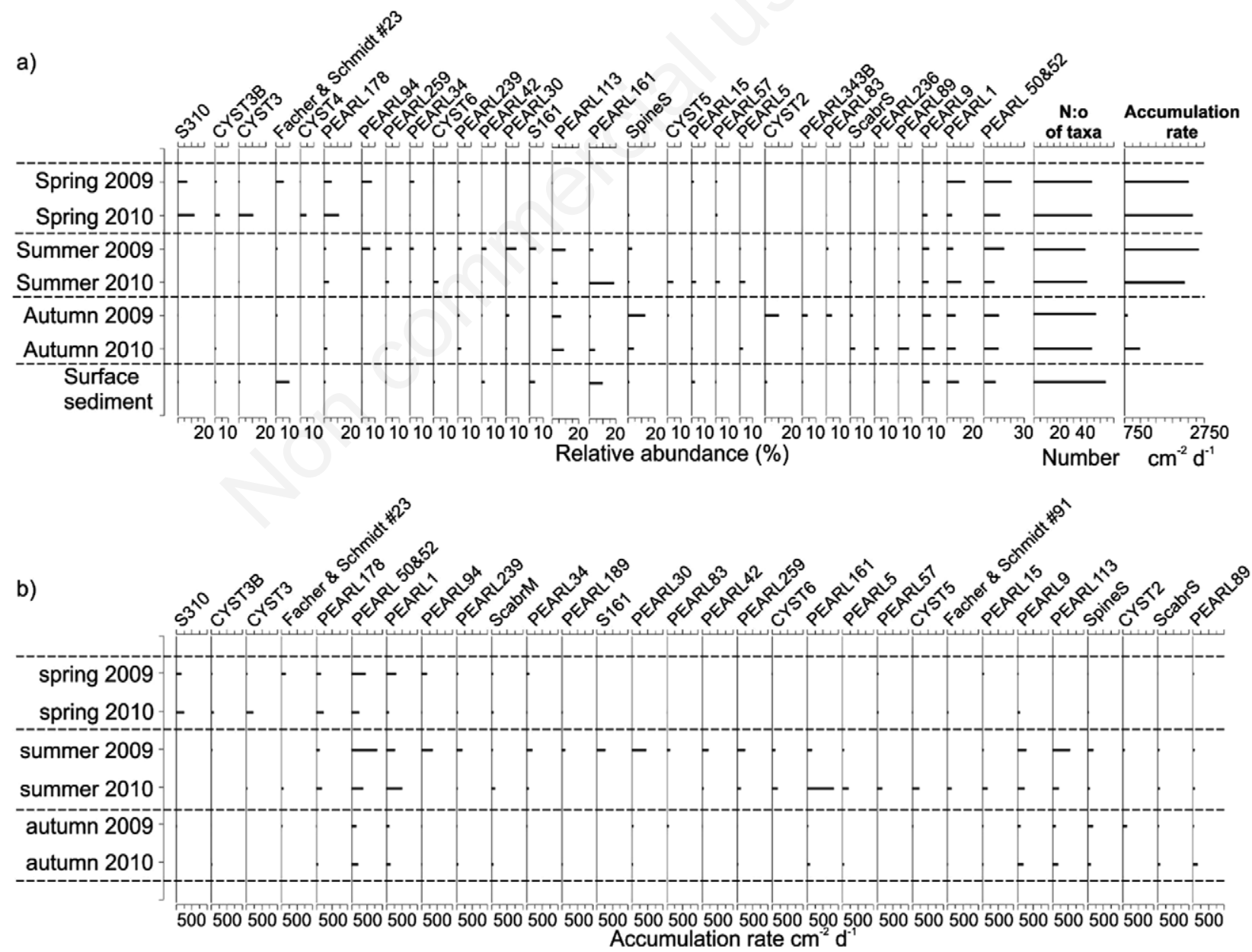

Fig. 2. a) Inter-annual seasonal differences of chrysophyte cyst morphotypes with a relative abundance $>3 \%$ in any sample; the rarefact-corrected number of taxa and accumulation rates are added after each stratigraphical diagram. b) Inter-annual seasonal differences of chrysophyte cyst morphotypes based on accumulation rate (chrysophyte cysts $/ \mathrm{cm}^{-2} \mathrm{y}^{-1}$ ) data. 
species data of both the sediment trap data and surface sediment assemblages (Fig. 4 a,b; ter Braak and Šmilauer, 2007-2012). In order to explore the relationship between the biota and the measured seasonal environmental variables, redundancy analysis (RDA) and partial RDA was used. The surface sediment sample was added passively to the RDA plot, hence not affecting the species-environmental relationship (Fig. 4 c,d). Since no accumulation rate data was available for the surface sediment sample, species relative abundance data was used in PCA and RDA. All species were transformed to percentage abundances and square-root transformed prior to the statistical analyses, which were performed using CANOCO 5.01 (ter Brak and Šmilauer, 2007-2012). All taxa were included in the PCA and RDA, however, only the most common taxa (the same as in Figs. 2a and 3a) were plotted in Fig. 4.

a)

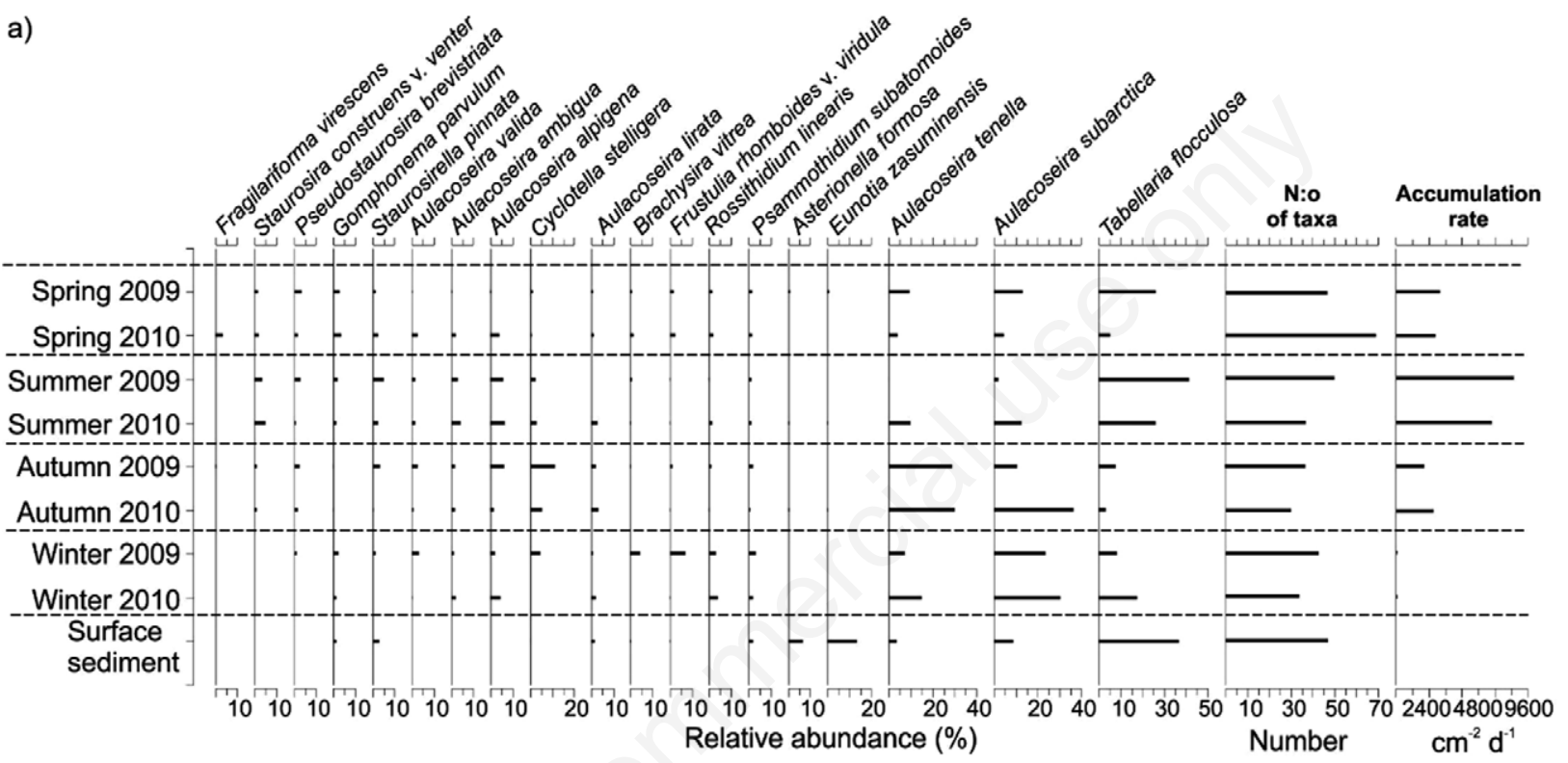

b)

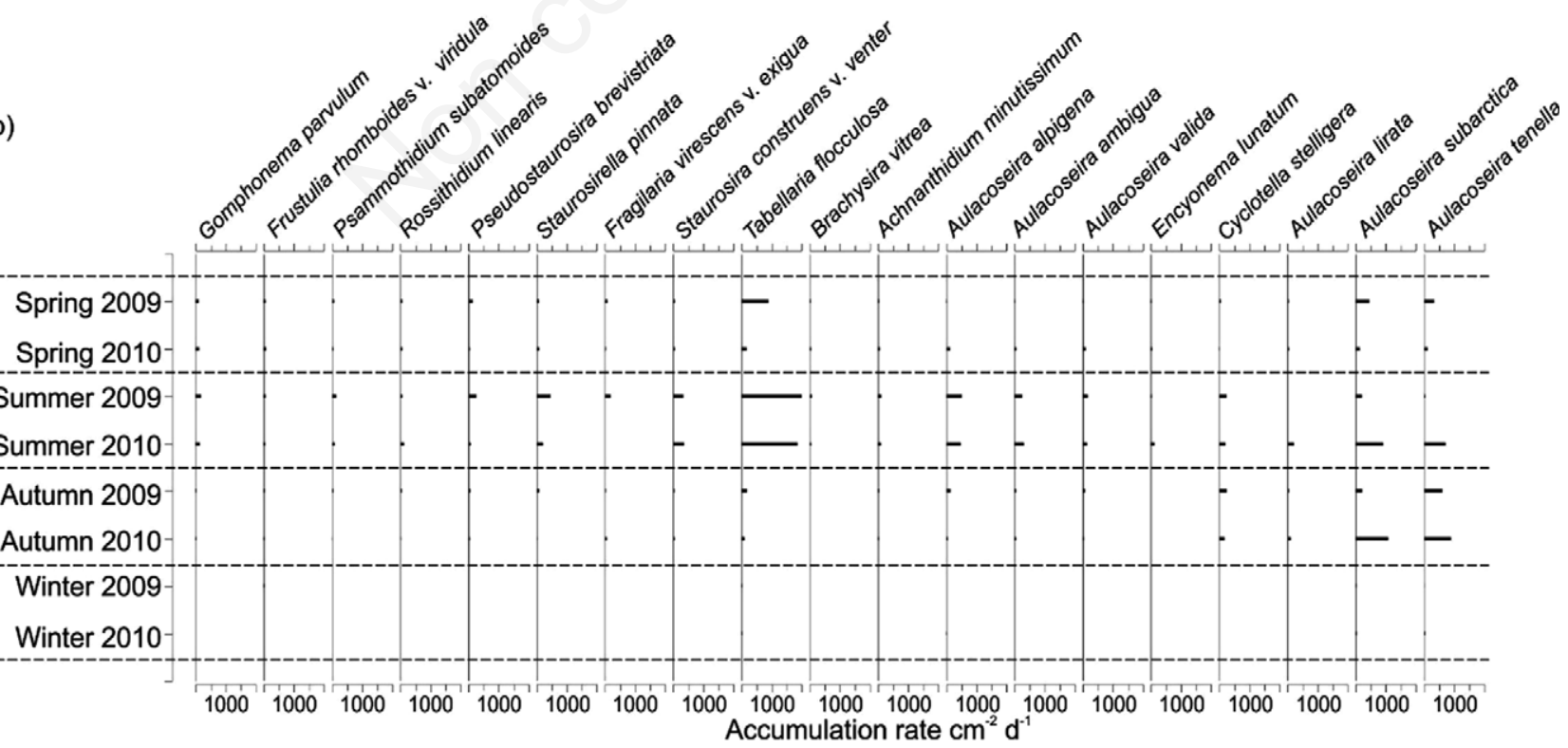

Fig. 3. a) Inter-annual seasonal differences of diatoms with a relative abundance $>3 \%$ in any sample; the rarefact-corrected number of taxa and accumulation rates are added after each stratigraphical diagram. b) Inter-annual seasonal differences of diatoms based on accumulation rate (diatoms $/ \mathrm{cm}^{-2} \mathrm{y}^{-1}$ ) data. 


\section{RESULTS}

\section{Environmental conditions}

The mean seasonal air temperatures and mean seasonal precipitation values between the trapping periods and also between the two years varied considerably (Finnish Meteorological Institute, 2012). The year 2009 had minor seasonal contrasts. In addition, it had a warm winter and low amount of snow. The year 2010, in contrast, had strong seasonality characterised by a colder and snowy winter and warmer summer (Ojala et al., 2013). a)

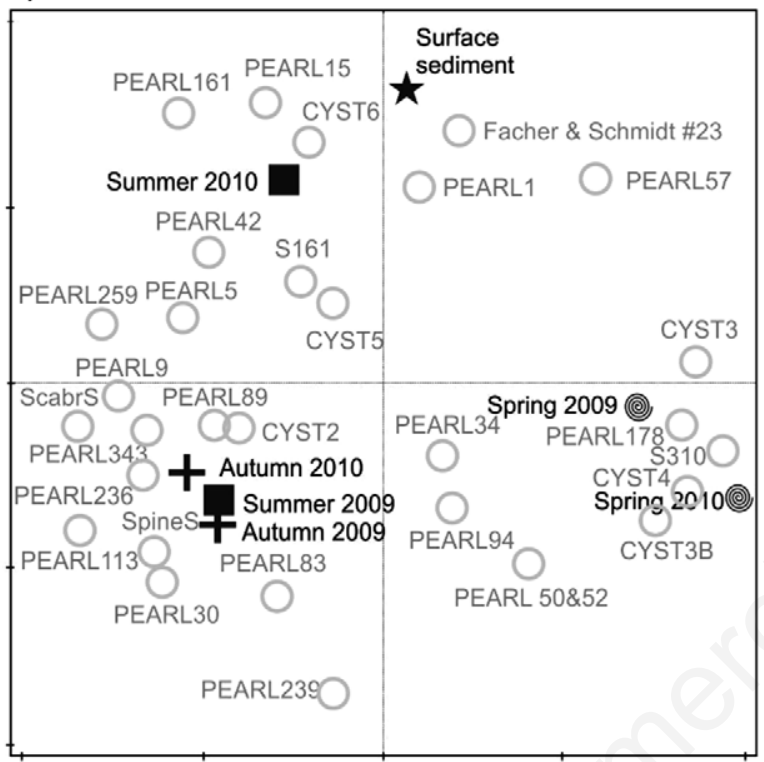

b)

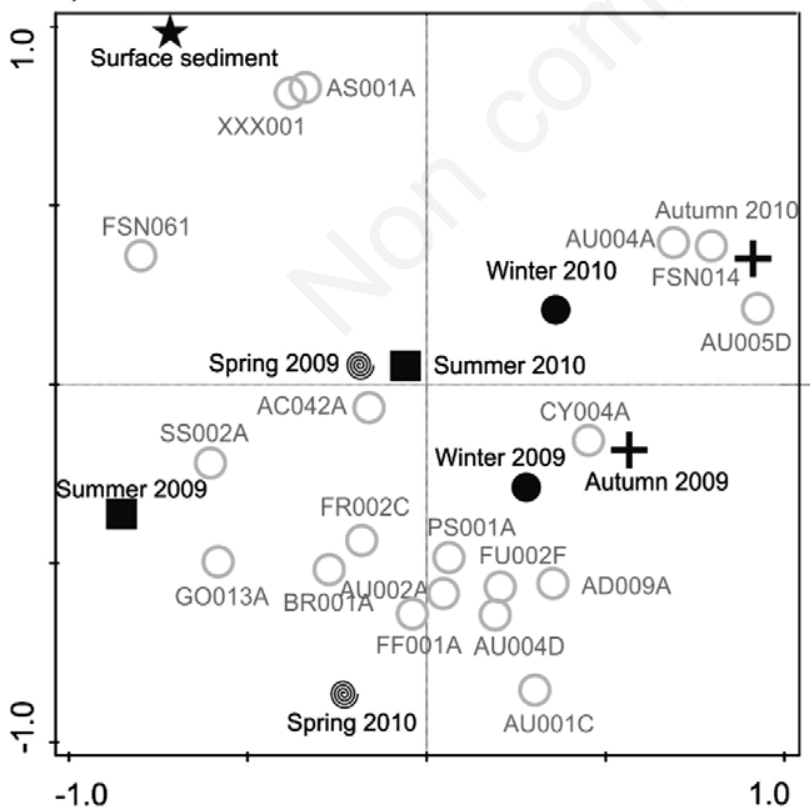

c)

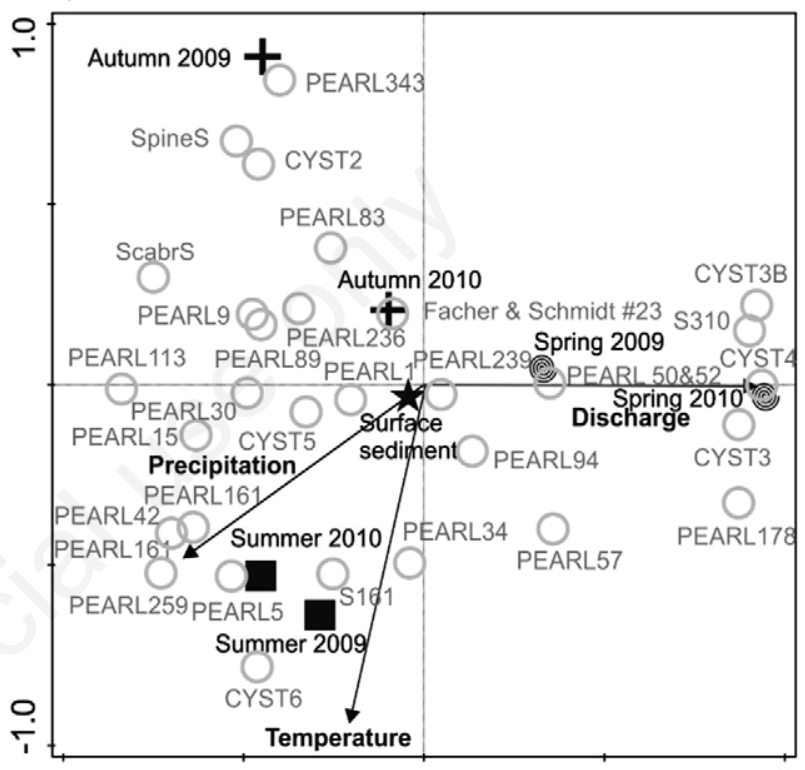

d)

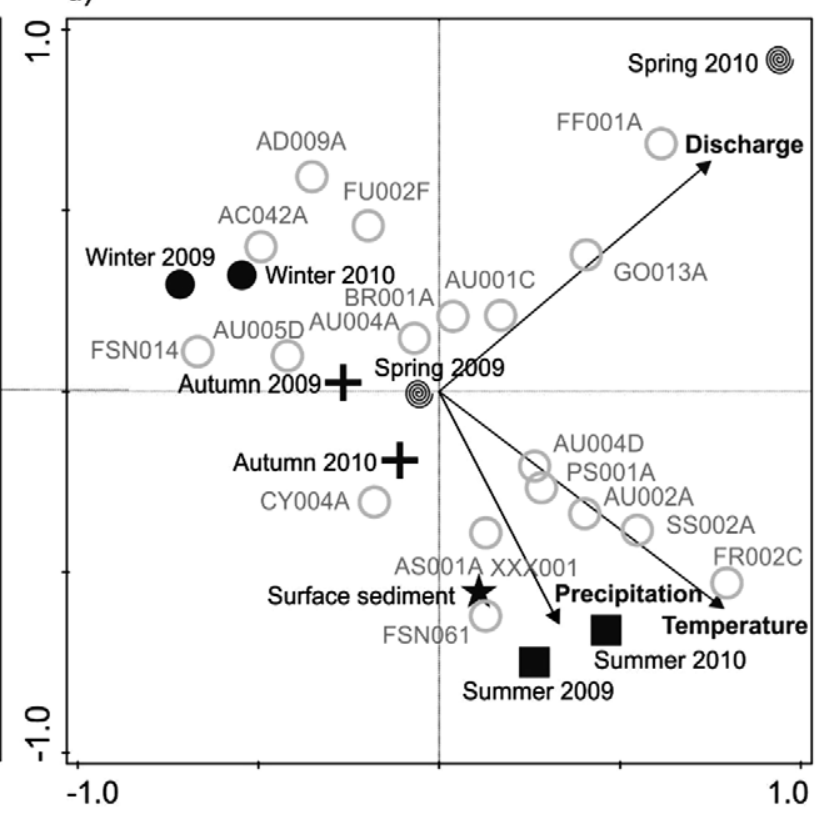

Fig. 4. Principal component analysis (PCA) of relative abundances of seasonal cyst samples and surface sediment sample (a) and seasonal diatom samples and surface sediment sample (b). The relationship between measured seasonal environmental variables (based on daily averages of the period of time the sediment traps were employed) and relative abundances of chrysophyte cysts (c) and diatom taxa (d) are plotted as a redundancy analysis (RDA) ordination biplot. The surface sediment sample was included as a supplementary variable in the RDA. 
The discharge values from Lake Äväntäjärvi reveal also clear differences between the monitored seasons and different years. The spring runoff peak was low in 2009 due to the low snow cover and short snow cover period and the generally warmer and wetter winter in 2008/2009, with frequent thawing and flooding cycles. During 2010, however, a distinct peak in discharge occurred after the melting of snow, whereas it was low during summer. Discharge increased again in autumn due to rain events (Ojala et al., 2013).

\section{Chrysophyte cysts}

A total of 103 cyst types (morphotypes or collective categories) were identified in sediment trap samples during the two years, 30 of which had a minimum occurrence $>3 \%$ in at least one sample (Fig. 2a). Cyst accumulation rates were highest in spring and summer samples and considerably lower in autumn and winter samples (Fig. 2a). Winter trap samples were excluded from the analyses due to extremely low amount of cysts. The amount of different morphotypes in samples varied slightly between seasons and the two years. The lowest diversity of cyst types in sediment traps was found in summer trap samples, 39 morphotypes in 2009 and 38 in 2010 while the highest (47 morphotypes) was found in autumn 2009 (Fig. 2a).

Some subtle differences were observed in cyst assemblages during the same season but different years (Fig. 2). Most likely previously unknown cyst morphotypes CYST3, CYST3B and CYST4 (Supplementary Fig. 1) were mainly found in the spring 2010 sample (Fig. 2a). Six cyst types (S310, CYST3, CYST3B, CYST4, PEARL 178, Facher\&Schmidt \#23) had their highest accumulation rate during spring (Fig. 2b; Supplementary Tab. 1). PEARL 34, PEARL 94 and also PEARL 178 were most common in both spring and summer samples. Most of the cyst types (22 out of 30, e.g. PEARL 161 and PEARL 30) had their highest accumulation rates during summer and three cyst types (PEARL 89, ScabrS, CYST 2) in autumn (Fig. 2b, Supplementary Tab. 2). Among the most common cyst types were three cyst types occurring in all sam- ples (Fig. 2). These are collective categories (PEARL 50\&52, PEARL 1, PEARL 9), which are most likely produced by several different species of chrysophytes (Duff et al., 1995).

According to RDA, spring sediment trap samples for both years show a strong positive correlation with discharge intensity. Summer samples show a positive correlation with precipitation and temperature while autumn samples during both years show a negative correlation with temperature (Fig. 4c). According to partial RDA, only discharge explains statistically significantly the variance in the cyst data (Tab. 2).

\section{Diatoms}

A total of 105 diatom taxa were identified in sediment trap samples, 19 of which with a minimum occurrence $>3 \%$ in at least one sample (Fig. 3a). Diatom accumulation rate was highest in summer samples and lower in autumn and winter samples (Fig. 3a). Accumulation rates between years 2009 and 2010 were relatively similar. The number of diatom species varied between the years, but were highest either in spring (69 in spring 2010) or during summer and lowest during autumn (31 in autumn 2010; Fig. 3a).

Inter-annual diatom samples of the same seasons were in general relatively similar (Fig. 3). The majority of the most common species were identified in both years and clearer changes could only be seen in a few species like Tabellaria flocculosa (Roth) Kützing, Aulacoseira tenella (Nygaard) Simonsen, and Aulacoseira subarctica (O. Müller) Haworth (Fig. 3). Only Frustulia rhomboides v. viridula (Brébisson) Cleve had its highest accumulation rate during spring. Almost all of the most common diatoms shown in Fig. 3 (15 out of 19) had their highest accumulation rate during summer, and three $[A$. tenella, A. subarctica, Cyclotella stelligera (Cleve \& Grun. in Cleve)] during autumn (Fig. 3b, Supplementary Tab. 2). None of the diatom taxa had a maximum accumulation rate during winter (Supplementary Tab. 1).

According to RDA, summer trap samples of both years are positively correlated and the winter trap sam-

Tab. 2. Results of constrained (variance explained) and partial (unique contribution) redundancy analysis (RDA) and Monte Carlo permutation tests (999 permutations) for assessing the environment-species relationships. Variance explained refers to the explanatory power of the variable. Unique contribution refers to the explanatory power of the variable after partialling out the effect of the other measured variables.

\begin{tabular}{lccc} 
& Variance explained $(\%)$ & P value & Unique contribution (\%) \\
& C/D & C/D & C/D \\
Discharge & $31.8 / 18.4$ & $0.006 / 0.26$ & $21.5 / 16.7$ \\
\hline Temperature & $16.9 / 18.8$ & $0.65 / 0.15$ & $16.0 / 13.0$ \\
\hline Precipitation & $23.4 / 13.1$ & $0.26 / 0.55$ & $0.56 / 0.50$ \\
\hline
\end{tabular}

C, cysts; D, diatoms. 
ples of both years are negatively correlated with precipitation and air temperature (Fig. 4d). Both autumn samples and the spring sample of 2009 show less correlation to any measured environmental variable. The spring trap sample of 2010, however, is strongly correlated with discharge (Fig. 4d). According to partial RDA none of the environmental variables explain the variance in the diatom data statistically significantly (Tab. 2).

\section{Comparison between surface sediment- and trap samples}

All together 54 cyst morphotypes were found in the sediment surface, which makes it more diverse than the assemblages found in sediment traps (varying between 39 and 47). The most commonly occurring cysts in trap samples are also present in the surface sediment sample (Fig. 2a). The surface sediment sample included six cyst morphotypes with an occurrence over 3\% in both sediment traps and surface sediment. These six morphotypes comprised $48 \%$ of all the identified cysts in the sediment sample. According to PCA, the surface sediment sample is most similar with the summer 2010 trap sample (Fig. 4a), but is in general not well correlated with the other seasonal trap samples. Based on RDA, none of the environmental variables seem to explain the overall variation in the cyst data as the surface sediment sample is located very close to the origo (Fig. 4c).

The surface sediment sample of diatoms consisted of 30 taxa comprising the majority of the most common diatom taxa found in the sediment trap samples (Fig. 3a). The surface sediment sample included only four taxa with an occurrence over $3 \%$, all of which were found in the trap samples (Fig. 3a). However, 13 out of 17 of the most common diatoms found in the trap samples had a lower occurrence than $3 \%$ in the surface sediment sample. According to PCA, the diatom assemblage of the surface sediment sample differs from the diatom assemblages of the trap samples (Fig. 4b). Based on RDA, precipitation and temperature have a higher explanatory power on the overall variation in the surface sediment diatom composition than discharge (Fig. 4d).

\section{DISCUSSION}

In Nautajärvi diatoms are more abundant than chrysophyte cysts. Both chrysophyte cysts and diatoms show a seasonal succession indicated by the different spring, summer, autumn, and winter assemblages. There are cyst types in Lake Nautajärvi, which mainly prefer a certain season, but also taxa that occur throughout the growing season. The same pattern can also be seen in diatom assemblages, although less clearly (Figs. 2 and 3; Supplementary Tabs. 1 and 2).

\section{Algal accumulation rates and number of species}

The accumulation rate of chrysophyte cysts is rather similar during spring and summer, whereas the accumulation rate of diatoms is highest during summer (Figs. 2a and 3a). The summer peak of diatoms is somewhat surprising, as diatoms are often thought to bloom in spring and/or in autumn (Lotter and Bigler, 2000; Rautio et al., 2000). One explanation for this discrepancy might be that the sediment traps were emptied on the 28th of May in 2009 and on the 24th of May in 2010, only a few weeks after the ice melt. Thus, the bulk of the diatom 'summer' peak might be the late portion of the actual spring bloom underestimating the accumulation rates of the spring bloom and overestimating the accumulation rates of summer. The latter explanation is supported by accumulation data from Ojala et al. (2013), who suggested that an increase in spring run-off and sediment deposition often results in surplus sedimentation during early summer. Both cyst and diatom accumulation rates decrease strongly towards autumn (Figs. 2a and 3a). However, the autumnal accumulation rates during 2009 are biased as the trap was removed as late as in January 2010 increasing the number of trap days during winter when algal production is generally low (Figs. 2a and 3a; Supplementary Tabs. 1 and 2). The inter-annual accumulation rates of both algal groups are very similar despite the climatological and hydrological differences, whereas the intra-annual accumulation rates differ substantially. This suggests that aquatic organisms are more dependent on prevailing seasonal limnological conditions (e.g., spring and autumnal overturn, summer stagnation) than on rapid, shortly lived episodes such as the spring discharge peak, which occurred in 2010. The number of chrysophyte cysts morphotypes varied only slightly between seasons, whereas more change could be observed in the diatom taxa (Figs. 2a and 3a). The peak number of diatom taxa in spring 2010 could be explained by the increased in-wash from the catchment and from the three inflows due to the strong spring discharge after the snowmelt, although no clear signs of lotic diatoms can be seen (Fig. 3). Chrysophyte morphotypes instead seem to be of more autochthonous origin and less sensitive to external inputs (Fig. 2).

\section{Seasonal changes between years}

The clearly different weather and hydrological conditions during the monitored two years do not seem to have had a profound effect on the cyst and diatom assemblages between the seasons in lake Nautajärvi (Figs. 2 and 3), although some subtle differences occur. Morphotypes CYST3, CYST3B, CYST4 and PEARL 178 seem to have benefited from the higher discharge into the lake in spring 2010 while the environmental conditions of 2009 favoured the more common types PEARL 1, PEARL 94, PEARL 
50\&52, Facher \& Schmidt \#23 (Facher \& Schmidt, 1996) and PEARL 34 (Fig. 2). Melting snow caused the spring discharge to be much greater in 2010, which can also be seen in the position of the two spring samples in the RDA graph (Fig. 4c). Cyst assemblages in Lake Nautajärvi deposited during summer months were more affected by the amount of precipitation and air temperature.

Although subtle, the differences seen in the diatom assemblages between the seasons of two weatherwise different years occurred during spring, summer and in autumn (Figs. 3, 4b). This is not surprising as $2010 \mathrm{had}$ cooler winter temperatures, significantly more snow especially during spring, a considerably higher spring runoff peak and an autumnal discharge peak due to increased precipitation compared to 2009 (Ojala et al., 2013). These conditions have affected the occurrences of especially $A$. tenella and A. subarctica, which are known to thrive in well-circulating environments and cooler temperatures (Köster and Pienitz, 2006; Horn et al., 2011). Despite the highest number of species of all seasons, spring $2010 \mathrm{had}$ lower accumulation rates than spring 2009 (Fig. 3a). This, however, might be an artefact caused by the emptying of the traps during the ongoing spring bloom. Thus, it is possible that especially in 2010, where the spring turnover lasted longer, most of the summer occurrences of these two taxa are actually the 'tail' of the spring bloom.

The subtle differences between the spring, summer and autumn samples is also highlighted by PCA (Fig. 4b). However, in RDA only the importance of discharge in explaining the differences between the spring samples is well demonstrated (Tab. 2, Fig. 4d), whereas no clear difference between the other seasons can be seen.

Overall, the fact that the inter-annual accumulation rates of both algal groups were surprisingly similar and that prominent differences were noticed in seasonal sediment flux and varve components between these two monitoring years by Ojala et al. (2013) clearly enhances the need for a multi-proxy approach in sediment studies in order to better understand the past climate and environmental change. The multi-proxy approach comprises often well the seasonal differences in biota, which can then eventually be used for high resolution palaeoenvironmental studies.

\section{Seasonal differences within a year}

Environmental conditions during spring have been shown to be significant for chrysophyte cysts. Pla-Rabes and Catalan (2011) found a significantly larger number of characteristic cyst taxa affected by spring temperatures than cysts related to summer temperatures. In addition, a number of studies have shown chrysophyte stomatocyst concentrations to be highest after ice break up (Agbeti and Smol, 1995; Kamenik and Schmidt, 2005). However, studies by Eloranta (1986) on chrysophyte ecology and seasonality in Finnish lakes suggests that the number of chrysophyte taxa and biomass is the highest from July to September. In Nautajärvi most cysts are sedimented during summer (Fig. 2b). Of the identified cysts, Facher \& Schmidt \#23, CYST3, CYST3B, CYST4, S310, PEARL 178 were found in highest numbers in the spring samples (Supplementary 2). The cyst type S310 in Lake Nautajärvi resembles Facher and Schmidt's \#92 (1996) and Pla's S310 (2001) described from sediment material of lakes in the Pyrenees. This cyst prefers slightly acidic waters and long ice-cover (Facher and Schmidt, 1996; Pla, 2001). Pla and Catalan (2011) found S310 to be a typical cyst during spring. PEARL 178 occurs throughout the year but the numbers clearly peak during spring (Supplementary 2). This cyst type has been found worldwide (Duff et al., 1995; Pla, 2001). Currently, there is no data about the biological affinity or ecology of either PEARL 178 or S310.

PEARL 34, PEARL 94 and PEARL 178 occur in higher numbers both in spring and summer (Fig. 2b; Supplementary Tab. 1). PEARL 34 has been found commonly in acidic oligotrophic lakes, its biological affinity is yet unknown (Duff and Smol, 1991; Pla and Anderson, 2005; $\mathrm{Pla}, 2011)$. It has been classified as a summer cyst in PlaRabes and Catalan (2011). Pla-Rabes and Catalan (2011) also classified PEARL 94 as a typical summer cyst and occurring in oligotrophic lakes in the Pyrenees (Pla, 2001) and Greenland (Pla and Anderson, 2005). In this study PEARL 239 had its highest accumulation rate in summer 2009 , whereas previously it has been associated with the autumn mixing period (Pla-Rabes and Catalan, 2011).

The spring samples are strongly associated with the intensity of spring discharge (Fig. 4c). However, as there are no clear signs of the cyst types increase during spring (Fig. 2a) which could be caused by an input from the drainage area, one possible explanation for the spring types to occur in spring might be the acidic pulse associated with the melt of the slightly acidic snow. This is supported by the ecology of the most common spring types favouring oligotrophic to slightly acidic water (see above).

The greatest number of indicator cyst types linked to a certain season was found in summer samples. PEARL 5 has been found in cold oligotrophic lakes in Canada, United States, Pyrenees and Greenland (Duff and Smol, 1991; Duff and Smol, 1994; Pla and Anderson, 2005; PlaRabes and Catalan, 2011). Pla-Rabes and Catalan (2011) have classified this cyst as typical for autumn. PEARL 30 is most likely tolerant of a wide range of temperatures (Wilkinson et al., 2001). PEARL 57 has been found in several oligotrophic locations and is most likely produced by an acidophilic species (Rybak et al., 1991, cyst 180). Pla-Rabes and Catalan (2011) found this cyst type in spring traps which supports our assumption that our summer traps have also collected the end of the spring bloom. PEARL 15 and 42 are collective categories where several 
species may produce similar cysts. PEARL 42 was the most abundant and dominant cyst during summer in Lake Redon (Pla-Rabes and Catalan, 2011) which supports our data of this cyst type occurring during summer time (Supplementary Tab. 1).

PEARL 161 was found in summer and autumn samples during both years but the numbers were clearly higher in summer samples (Supplementary Tab. 1). PEARL 161 is produced by the mixotrophic chrysoflagellate Dinobryon divergens O.E Imhof. $D$. divergens is among the most typical phytoplankton taxa in oligotrophic and clear acidic boreal lakes in Finland (Lepistö and Rosenström, 1998). It has been described as pH-indifferent or alkaliphilic and seems to tolerate acid conditions very well (Lepistö and Rosenström, 1998). S161 resembles PEARL 161 except that it has an obconical collar instead of a cylindrical one and it has been described as an acidophilic species and therefore may be produced by another species (Pla, 2001). Cyst PEARL 113 was found in summer and autumn samples of both years. Pla-Rabes and Catalan (2011) have classified this as an autumn cyst. It is probably produced by an oligotrophic cool-water taxon (Rybak, 1986 as cysta stellata) with the cyst producing species still unknown. Most likely a portion of the 'summer' cysts are actually an artefact caused by the timing in emptying the sediment trap.

PEARL 89 had its highest accumulation rate in the autumn 2010 sample (Supplementary Tab. 1). Also, PlaRabes and Catalan (2011) found this to be an autumn cyst. This cyst type has previously also been found at least in Canada and United States in acidic, oligotrophic lakes (Duff and Smol, 1991). Also a small $(<5.9 \mu \mathrm{m})$ cyst type ornamented with spines (SpineS) has its highest accumulation rates in summer and autumn (Supplementary Tab. 2 ). This type is a collective category of spinose cyst types with some cysts showing signs of being immature and therefore possibly lacking some of the identification criteria. Some of the cysts included in this category might well simply be immature PEARL 83, which had its highest accumulation rate in the summer 2009 trap sample. PEARL 83 has been described as pH-indifferent (Rybak et al., 1991). PEARL 236 is likely produced by Mallomonas acaroides v. muskokana K.H.Nicholls (Siver, 1991). According to Siver $(1991,1995)$ it blooms in late spring and early summer and has a relatively high temperature optimum of $17.5^{\circ} \mathrm{C}$. In Lake Nautajärvi this cyst type was most common during autumn 2010. Stomatocyst 1 (Smol, 1984), produced by Mallomonas pseudocoronata Prescott, which forms cysts in the autumn (Smol, 1984) and PEARL 236 can be difficult to distinguish. In this case the cysts identified as PEARL 236 often possessed spines with corona-like apices which is typical for this cyst type.
The autumn trap samples show a trend towards lower temperatures (Fig. 4c). The autumn 2009 trap was emptied as late as in January 2010, thus the mean temperatures for that time period were much lower than the following year. This discrepancy can be seen as the different location of the two autumn samples in the RDA (Fig. 4c). Accumulation rates in Lake Nautajärvi were extremely low during winters 2009 and 2010 (Ojala et al., 2013). Other sediment trap studies on chrysophyte cysts seasonality show a similar pattern of cysts being practically non-existent in the water column during winter months (Facher and Schmidt, 1996; Pla-Rabes and Catalan, 2011; Ojala et al., 2013). The few cysts deposited during winter (Supplementary 2) appear to be a collection of cysts not referring to any particular season or having a unique composition. Winter diatom assemblages in Lake Nautajärvi most likely consist mainly of reworked material from the lake-bottom or are the 'tail' of the autumn trap samples as the autumnal season of 2009 lasted until January 2010 (Ojala et al., 2013).

Cyst types that can be found in all sediment trap samples are most likely produced by more than one species with similar morphologies but different ecological tolerances (Duff et al., 1995). One of the most common cyst types in Lake Nautajärvi is PEARL 50\&52 (Fig. 2). PEARL 50\&52 has been found in cold, oligotrophic lakes (Facher and Schmidt, 1996; Duff et al., 1995; Pla, 2001) and has been found to bloom during both spring and autumn overturn (Pla and Catalan, 2011). PEARL 1 and PEARL 9 (Fig. 2) are also most likely produced by several different species. Therefore, the information gained from their occurrence in the samples is quite limited. They appear to be widely distributed and tolerant of a wide range of environmental variables (Duff et al., 1995; Pla, 2001).

Only one diatom species (F. rhomboides v. viridula) had a clear spring maximum (Fig. 3b; Supplementary Tab. 2). This taxon is considered to favour slightly acidic to circumneutral waters (Krammer and Lange-Bertalot, 1986; Wolfe and Kling, 2001) i.e., similar water than in Lake Nautajärvi, especially after spring snow melt.

Although the majority of the most common diatom taxa were identified to have their maximum accumulation rate in summer, five taxa, (Aulacoseira ambigua (Grunow) Simonsen, Aulacoseira alpigena (Grunow) Simonsen, T. flocculosa, Staurosirella pinnata (Ehrenberg) Williams \& Round, and Staurosira construens v. venter (Ehrenberg) P.B Hamilton) occur at higher numbers mainly during summer (Fig. 3; Supplementary Tab. 2). A. ambigua is a common planktic species occurring often in high abundances in oligotrophic to mesotrophic waters mainly during spring blooms, but also in lower amounts during autumn blooms (Poister et al., 2012). The highest accumulation rates of diatoms during summer can again be explained by the prolonged spring bloom compared to 
the time of the summer trap sampling. This is also supported by the fact that $A$. ambigua has been shown to have a high silica demand (Kilham, 1990) and the highest silica concentration in Lake Nautajärvi occurs during the spring discharge period (Ojala et al., 2013). A. alpigena and T. flocculosa are commonly found in oligotrophic to mesotrophic, and slightly acidic environments (van Dam et al., 1994; Köster and Pienitz, 2006), such as Lake Nautajärvi. S. pinnata and S. construens v. venter seem to favour environments with slightly elevated $\mathrm{pH}$ (Schmidt et al., 2004), but as especially S. construens v. venter resembles taxa with different ecological preferences (Rumrich et al., 2000), its specific ecological niche is still not known.

Three planktic diatom taxa, A. tenella, A. subarctica, and $C$. stelligera had their highest accumulation rates during autumn. A. tenella and A. subarctica are among the most common taxa in Nautajärvi occurring in high abundances in all seasonal trap samples (Fig. 3). These two taxa are commonly found in oligotrophic and slightly acidic waters (van Dam et al., 1994; Köster and Pienitz, 2006), whereas C. stelligera seem to favour deeper lakes with prolonged ice-free periods and stronger thermal stratification (Rühland et al., 2003).

Diatom accumulation rates in Lake Nautajärvi are extremely low during winter (Fig. 3; Supplementary Fig. 1; Ojala et al., 2013). This is not surprising as environmental conditions under the ice cover do not favour their growth. Thus, the occurrence of especially planktic diatoms in the sediment traps during winter may be the result of small-scale resuspension. Although none of the diatom taxa had their maximum accumulation rate during winter, the relative abundance, however, of Rossithidium linearis m (W. Smith) Round \& Bukhtiyarova, Psammothidium subatomoides (Hustedt) Bukhtiyarova, Brachysira vitrea (Grunow) Ross \& Williams, and F. rhomboides v. viridula was highest during winter (Fig. 3a). These taxa are considered to favour slightly acidic to circumneutral waters (Krammer and Lange-Bertalot, 1986; Wolfe and Kling, 2001). The high amount of taxa occurring during all seasons in the trap samples (Fig. 3) suggests that diatoms are more dependent on prevailing seasonal conditions than on rapid, short-lived episodes.

There is a clear difference between the results of the two used approaches, namely species relative abundance and species accumulation rate (Figs. 2 and 3). As the former provides only the relative abundance of taxa in relation to each other the latter quantifies the occurrence of taxa, thus providing more reliable information of real changes occurring in the biological community. It is thus recommendable, that in studies where the occurrences of different taxa are compared accumulation rates should be used, if available.

\section{Representativeness of sediment trap data in the surface sediment sample}

The surface sediment sample of chrysophyte cysts and diatoms comprised rather well especially the most common species found in seasonal sediment traps (Figs. 2 and 3 ), and the most distinctive differences could only be seen among taxa with low occurrences.

The surface sediment sample of chrysophyte cysts was most diverse of all counted samples comprising 54 morphotypes (Fig. 2a) of which 13 morphotypes were not found in the trap samples. However, these 13 morphotypes were present only in small numbers and therefore circa $87 \%$ of all the cysts counted in the sediment surface sample were also present in the seasonal trap samples. This result is in line with a previous study conducted in Lake Redon in the Pyrenees (Pla-Rabes and Catalan, 2011) where cysts not occurring in the sediment traps showed relative abundances of only $<1 \%$ in the sediment core. These results contradict the findings by e.g. Siver and Hamer (1992) who studied the seasonal periodicity of Chrysophyceae and Synurophyceae from a small New English Pond. In their study the surface sediment sample comprised less than $50 \%$ of the total observed taxa indicating that the surface sediment sample does not reflect the true species richness. Such divergence, regardless of the processes causing them, has to be taken into account when conducting palaeolimnological analysis to infer fluctuations of past climate and environmental change. According to PCA, the surface sediment assemblage for chrysophyte cysts in lake Nautajärvi is most similar with the summer 2010 sediment trap assemblage, which in addition to summer taxa also most likely represents part of the late spring taxa. In general, no clear similarities can be seen (Fig. 4a). The difference in the similarity of inter-annual seasons and the surface sediment sample between Figs. $2 \mathrm{a}$ and $4 \mathrm{a}$ can be explained by the fact that in Fig. 2a only taxa with the occurrence of $>3 \%$ in any sample were included, whereas in Fig. 4a all taxa were included, although only the same taxa than in Fig. 2 are highlighted. Despite some differences in species diversity between the sediment trap and surface sediment assemblages in Lake Nautajärvi, the surface sediment sample represents well the whole-lake taxa richness and suggests that in such a small and rather shallow boreal lake with a simple singlebasin sedimentation environment, the surface sediment represents well overall species richness of prevailing algae.

The surface sediment sample comprised 30 diatom taxa of which four taxa were not found in the trap samples. In contrary, the trap samples comprised in total 105 taxa of which 77 taxa were not found in the sediment sample. However, the 30 taxa found in the surface sediment sample account on average for $67 \%$ of all the diatom taxa counted in the trap samples suggesting that the sediment sample represent well the whole-lake taxa richness, al- 
though PCA reveals differences between the trap and sediment sample (Fig. 4b). The differences in the ordination analysis could be explained by the diversity of periphytic taxa occurring in small abundances in the trap samples but not as frequently in the sediment sample (Fig. 3a). This is somewhat surprising since the depth $(20 \mathrm{~m})$, dystrophy and anoxic hypolimnion of Lake Nautajärvi (Ojala and Alenius, 2005) should favour the occurrence of plankton over periphyton by providing more suitable habitats for them. Planktic diatoms, however, comprise only ca. half of the diatom population. This suggests that the steep slopes of the lake enhance the transport of sediments and the three inflows and seasonal discharge support vertical mixing transporting periphytic diatoms within the lake. Similar results were also shown by Köster and Pienitz (2006) who explained the discrepancy between the proportion of epipelic diatoms in the trap samples and surface sediment sample by sediment focusing and vertical transport increasing the valve deposition in the traps. The location of the surface sediment sample in the PCA suggests that it is mainly a surrogate of all seasons and does not represent a particular season of the year (Fig. 4b). None of the environmental variables used in this study explain the diatom composition in the sediment trap assemblages statistically significantly (Tab. 2). As the surface sediment sample was added to the RDA as a supplementary variable it did not affect the analysis but is, however, plotted in the ordination diagram based on its species composition (Fig. 4d). The position of the surface sediment sample in the RDA (Fig. 4d) suggests that precipitation and temperature have the highest impact on the structure of its species composition. Although it has been shown that diatom distribution in freshwaters is mainly controlled by nutrients and $\mathrm{pH}$ (Bennion, 1994; Weckström et al., 2003), these environmental variables are strongly impacted by precipitation and temperature due to external and internal physico-chemical processes. Moreover, although Anderson (2000) has highlighted some issues when relating diatoms directly to air temperature, it has also been shown to be a strong environmental variable controlling diatom distribution (Weckström et al., 1997; Weckström et al., 2006).

No signs of any taphonomical processes could be found. Regarding its morphology (size, depth), our study lake is representative of a small and shallow circumpolar lake often used in palaeolimnological studies. According to Downing et al. (2006), small and shallow lakes constitute over $90 \%$ of the world's lakes of which 187888 lakes over 0.05 ha are situated in Finland (Raatikainen and $\mathrm{Ku}$ usisto, 1990). Thus, within small and shallow lakes without any extreme environmental setting (Ryves et al., 2003) no taphonomical difficulties should be met. Moreover, in such lakes a single surface sediment sample collected from the representative sedimentation basin comprises generally well the algal population of the lake and can thus be used with appropriate caution in palaeolimnological studies.

\section{CONCLUSIONS}

Despite the different prevailing weather and hydrological conditions between the study years 2009 and 2010, the inter-annual accumulation rates of chrysophyte cysts and diatoms were relatively similar, whereas the intra-annual accumulation rates differed substantially. The seasonality of the sediment trap samples was highlighted by RDA as spring samples were positively correlated with spring discharge, summer samples with precipitation and air temperature, whereas autumnal and winter samples were negatively correlated with precipitation and air temperature. The high amount of taxa occurring during all seasons in the trap samples and the similarity between the inter-annual assemblages implies that primary producers are more dependent on prevailing seasonal limnological conditions than on rapid, shortly lived episodes.

Although some dissimilarities between the sediment trap assemblages and the surface sediment assemblages can be seen, most of the chrysophyte cysts and diatoms thriving in Lake Nautajärvi are well preserved and presented in the surface sediment sample. This suggests that the surface sediment sample of small and shallow lakes without any extreme environmental settings comprises generally well the lake's overall algal composition and can thus be utilised with appropriate caution in palaeolimnological studies.

\section{ACKNOWLEDGEMENTS}

This research was supported by the Academy of Finland CLIM-ECO project, Academy of Finland QUALproject (A.E.K. Ojala, grant\# 259343) and Tellervo ja Juuso Waldenin Säätiö (S. Korkonen).

\section{REFERENCES}

Agbeti MD, Smol JP, 1995. Chrysophyte population and encystment patterns in two Canadian lakes. J. Phycol. 31:70-78.

Anderson NJ, 2000. Diatoms, temperature and climatic change. Eur. J. Phycol. 35:307-314.

Battarbee RW, Kneen MJ, 1982. The use of electronically counted microspheres in absolute diatom analysis. Limnol. Oceanogr. 27:184-188.

Battarbee RW, 1986. Diatom analysis, p. 527-570. In: B.E. Berglund (ed.), Handbook of Holocene Palaeoecology and Palaeohydrology. Wiley.

Baumann E, de Jong R, Kamenik C, 2010. A description of sedimentary chrysophyte stomatocysts from high-Alpine Lake Silvaplana (Switzerland). Nova Hedwigia Beiheft 136:71-86. 
Bennion H, 1994. A diatom-phosphorus transfer function for shallow, eutrophic ponds in southeast England. Hydrobiologia 275/276:391-410.

Birks HJB, Line JM, 1992. The use of rarefaction analysis for estimating palynological richness from Quaternary pollenanalytical data. Holocene 2:1-10.

Cronberg G, Sandgren CD, 1986. A proposal for the development of standardized nomenclature and terminology for chrysophycean statospores, p. 317-328. In: J. Kristiansen and R.A. Andersen (eds.), Chrysophytes: Aspects and problems. Cambridge University Press.

De Jong, R, Schneider, T, Hernandez-Almeida, I, Grosjean, M, 2016. Recent temperature trends in the South Central Andes reconstructed from sedimentary chrysophyte stomatocysts in Laguna Escondida (1742 m a.s.1., $38^{\circ} 28 \mathrm{~S}$, Chile). Global Planet. Change 137:24-34.

Dixit SS, Smol JP, Kingston JC, Charles DF, 1992. Diatoms: Powerful indicators of environmental change. Environ. Sci. Technol. 26:22-33.

Downing J, Prairie Y, Cole J, Duarte C, Tranvik L, Striegl R, McDowell W, Kortelainen P, Caraco N, Melack J, 2006. The global abundance and size distribution of lakes, ponds, and impoundments. Limnol. Oceanogr. 51:2388-2397.

Duff KE, Smol JP, 1991. Morphological descriptions and stratigraphic distributions of the chrysophycean stomatocysts from a recently acified lake (Adirondack Park, N.Y.). J. Paleolimnol. 5:73-113.

Duff KE, Smol JP, 1994. Chrysophycean cyst flora from British Columbia (Canada) lakes. Nova Hedwigia 58:53-389.

Duff KE, Zeeb BA, Smol JP, 1995. Atlas of Chrysophycean Cysts. Developments in hydrobiology 99. Kluwer Academic Publishers, The Netherlands: 189 pp.

Eloranta P, 1986. Phytoplankton structure in different lake types in central Finland. Holoarctic Ecol. 9:214-224.

Facher E, Schmidt R, 1996. A siliceous chrysophycean cystbased $\mathrm{pH}$ transfer function for Central European lakes. J. Paleolimnol. 16:275-321.

Finnish Meteorological Institute 2012. Available at: http://en.ilmatieteenlaitos.fi/open-data-manual.

Forsström L, Sorvari S, Korhola A, 2009. Phytoplankton in subarctic lakes of Finnish Lapland - implications for ecological lake classification. Adv. Limnol. 62:77-97.

Hammer Ø, Harper DAT, Ryan PD, 2001. PAST: Paleontological statistics software package for education and data analysis. Palaeontologia Electronica 4:9 pp.

Hausmann S, Pienitz R, 2007. Seasonal climate inferences from high-resolution modern diatom data along a climate gradient: a case study. J. Paleolimnol. 38:73-96.

Hernandez-Almeida, I, Grosjean, M, Przybylak, R, Tylmann, W, 2015. A chrysophyte-based quantitative reconstruction of winter severity from varved lake sediments in NE Poland during the past millennium and its relationship to natural climate variability. Quaternary Sci Rev. 122:74-88.

Hill MO, Gauch HG, 1980. Detrended correspondence analysis: an improved ordination technique. Vegetatio 42:47-58.

Horn H, Paul L, Horn W, Petzoldt T, 2011. Long-term trends in the diatom composition of the spring bloom of a German reservoir: is Aulacoseira subarctica favoured by warm winters? Freshwater Biol. 56:2483-2499.

Juggins S, 2007. C2 Version 1.5: User guide, software for eco- logical and palaeoecological data analysis and visualization. University of Newcastle, Newcastle upon Tyne.

Juggins S, 2013. Quantitative reconstructions in paleolimnology: a new paradigm or sick science? Quaternary Sci. Rev. 64:20-32.

Kamenik C, Agusti-Panareda A, Appleby P-G, Dearing JA, Shilland EM, Šporka F, Thomson R, 2005. Paleolimnological evidence for atmospheric pollution, climate and catchmentrelated changes in alpine chrysophyte stomatocyst assemblages (Tatra, Slovakia). Nova Hedwigia Beiheft 128: 275-293.

Kamenik C, Schmidt R, 2005. Chrysophyte resting stages a tool for reconstructing winter/spring climate from alpine lake sediments. Boreas 34:477-489.

Kilham P, 1990. Ecology of Melosira species in the Great Lakes of Africa, p. 414-427. In: M.M. Tilzer, C. Serruya (eds.), Large lakes, ecological structure and function. Springer-Verlag.

Krammer K, Lange-Bertalot H, 1986. [Bacillariophyceae. 1. Teil: Naviculaceae]. In: H. Ettl, J. Gerloff, H. Heynig, D. Mollenhauer (eds.), [Süsswasserflora von Mitteleuropa].[Book in German]. Gustav Fisher Verlag, Jena, Germany: 876 pp.

Krammer K, Lange-Bertalot H, 1988. [Bacillariophyceae. 2. Teil: Bacillariaceae, Epithemiaceae, Surirellaceae]. In: H. Ettl, J. Gerloff, H. Heynig and D. Mollenhauer (eds.) Süsswasserflora von Mitteleuropa].[Book in German]. Gustav Fisher Verlag, Stuttgart, Germany: 596 pp.

Krammer K, Lange-Bertalot H, 1991a. [Bacillariophyceae. 3. Teil: Centrales, Fragilariaceae, Eunotiaceae. In: H. Ettl, J. Gerloff, H. Heynig and D. Mollenhauer (eds.), [Süsswasserflora von Mitteleuropa].[Book in German]. Gustav Fisher Verlag, Stuttgart, Germany: 576 pp.

Krammer K, Lange-Bertalot H, 1991b. [Bacillariophyceae. 4. Teil: Achnanthaceae. Kritishe Ergänzungen zu Navicula (Lineolatae) und Gomphonema]. In: H. Ettl, G. Gärtner, J. Gerloff, H. Heynig and D. Mollenhauer (eds.), [Süsswasserflora von Mitteleuropa].[Book in German]. Gustav Fisher Verlag, Stuttgart, Germany: 437 pp.

Kujansuu R, Erviö R, Herola E, Hyyppä J, Kae E, Lahermo P, Raikamo E, Stén,C-G, Taka M, 1981. Explanation to the maps of surficial deposits, sheets 2142 01-12. Geological Survey of Finland, Espoo, Finland: 44 pp.

Köster D, Pienitz R, 2006. Seasonal diatom variability and paleolimnological inferences - a case study. J. Paleolimnol. 35:395-416.

Lampert W, Sommer U, 1997. Limnoecology: The ecology of lakes and streams. Oxford University Press, Oxford: 382 pp.

Lepistö L Rosenström U, 1998. The most typical phytoplankton taxa in four types of boreal lakes. Hydrobiologia 369/370:89-97.

Lotter AF, Bigler C, 2000. Do diatoms in the Swiss Alps reflect the length of ice-cover? Aquat. Sci. 62:125-141.

Moore JW, 1978. The distribution and abundance of phytoplankton 153 lakes, rivers and pools in the Northwest Territories. Can. J. Bot. 56:1765-1773.

Maier D, Gälman V, Bigler C, Renberg I, 2013. Tracing diatom assemblages through the water column into the sediment. Geophysical research Abstracts 15, EGU2013-11336. EGU General Assembly 2013.

OIVA, 2015. OIVA - The environmental and geographical information service, Finland's environmental administration. 
Accessed on: October 2015. Available from: http://wwwp2. ymparisto.fi/scripts/oiva.asp

Ojala AEK, 2001. Varved lake sediments in southern and central Finland: long varve chronologies as a basis for Holocene palaeoenvironmental reconstructions. Ph.D. dissertation, Geological Survey of Finland, Espoo.

Ojala AEK, Alenius T, 2005. 10000 years of interannual sedimentation recorded in the Lake Nautajärvi (Finland) clastic-organic varves. Palaeogeogr. Palaeoclimatol. Palaeoecol. 219:285-302.

Ojala AEK, Kosonen E, Weckström J, Korkonen S, Korhola A, 2013. Seasonal formation of clastic-biogenic varves: the potential for palaeoenvironmental interpretations. GFF 135:237-247.

Pla S, 2001. Chrysophycean cysts from the Pyrenees. Bibliotheca Phycologica Band 109. Cramer in der Gebrüder Borntraeger, Germany: $179 \mathrm{pp}$.

Pla S, Anderson NJ, 2005. Environmental factors correlated with chrysophyte cyst assemblages in low arctic lakes of southwest Greenland. J. Phycol. 41:957-974.

Pla-Rabes S, Catalan J, 2011. Deciphering chrysophyte responses to climate seasonality. J. Paleolimnol. 46:139-150.

Poister D, Kurth A, Farrel A, Gray S, 2012. Seasonality of Aulacoseira ambigua and filament length: biogeochemical implications. Plankton Benthos Res. 7:55-63.

Putkinen S, Saarelainen J, 1998. [A lighter model of Kullenberg's sampler].[Article in Finnish]. Geologi 50:22-23.

Raatikainen M, Kuusisto E, 1990. The number and surface area of the lakes in Finland. Terra 102:97-110.

Rautio M, Sorvari S, Korhola A, 2000. Diatom and crustacean zooplankton communities, their seasonal variability and representation in the sediments of subarctic Lake Saanajärvi. J. Limnol. 59:81-96.

Rühland K, Smol JP, Pienitz R, 2003. Ecology and spatial distributions of surface-sediment diatoms from 77 lakes in the subarctic Canadian treeline region. Can. J. Botany. 81:57-73.

Rumrich U, Lange-Bertalot H, Rumrich H, 2000. Diatoms of the Andes from Venezuela to Patagonia/Tierra del Fuego. Iconographia Diatomologica 9:1-649.

Rybak M, Rybak I, Nicholls K, 1991. Sedimentary chrysophycean cyst assemblages as paleoindicators ion acid sensitive lakes. J. Paleolimnol. 5:19-72.

Rybak M, 1986. The chrysophycean paleocyst flora of the bottom sediments of Kortowskie Lake (Poland) and its ecological significance. Hydrobiologia 140:67-84.

Ryves DB, Jewson DH, Sturm M, Battarbee RW, Flower RJ, Mackay AW, Granin N, 2003. Quantative and qualitative relationships between planktonic diatom communities and diatom assemblages in sedimenting material and surface sediments in lake Baikal, Siberia. Limnol. Oceanogr. 48:1643-1661.

Salmi P, Salonen K, 2016. Regular build-up of the spring phytoplankton maximum before ice-break in a boreal lake. Limnol. Oceanogr. 61:240-253.

Sandgren CD, 1983. Morphological variability in populations of chrysophycean resting cysts. I. Genetic (interclonal) and encystment temperature effects on morphology. J. Phycol. 19:64-70.

Sandgren CD, 1988. The ecology of chrysophyte flagellates: their growth and Perennation strategies as freshwater phytoplankton p. 9-104. In: C.D. Sandgren (ed.), Growth and reproductive strategies of freshwater phytoplankton. Cambridge University Press.

Sandgren CD, Smol JP, Kristiansen J (eds.), 1995. Chrysophyte Algae: Ecology, phylogeny and development. Cambridge University press, UK: 329 pp.

Schmidt R, Kamenik C, Lange-Bertalot H, Klee R, 2004. Fragilaria and Staurosira (Bacillariophyceae) from sediment surface of 40 lakes in the Austrian Alps in relation to environmental variables, and their potential for palaeoclimatology. J. Limnol. 63:171-189.

Siver PA, 1991. The stomatocyst of Mallomonas acaroides v. muskokana (Chrysophyceae). J. Paleolimnol. 5:11-17.

Siver P A, Hamer JS, 1992. Seasonal periodicity of Chrysophyceae and Synurophyceae in a small New-England lake - implications for paleolimnological research. J. Phycol. 28:186-198.

Siver PA, 1995. The distribution of chrysophytes along environmental gradients: their use as biological indicators, p. 232268. In: C.D. Sandgren, J.P. Smol and J. Kristiansen (eds.), Chrysophyte algae. Ecology, phylogeny and development. Cambridge University Press.

Smol JP, 1984. The statospore of Mallomonas pseudocoronata (Mallomonadaceae, Chrysophyceae). Nord. J. Bot. 4:827-831.

ter Braak CJF, Šmilauer P, 2007-2012. Canoco Reference Manual and User's Guide: Software for 623 Ordination version 5.0. Microcomputer power, Itaca: $496 \mathrm{pp}$.

van Dam H, Mertens A, Sinkeldam J, 1994. A coded checklist and ecological indicator values of freshwater diatoms from the Netherlands. Neth. J. Aquat. Ecol. 28:117-133.

Weckström J, Korhola A. Blom T, 1997. Temperature patterns over the past eight centuries in northern Fennoscandia inferred from sedimentary diatoms. Quaternary Res. 66:78-86.

Weckström J, Snyder JA, Korhola A, Laing TE, MacDonald GM, 2003. Diatom inferred acidity history of 32 lakes on the Kola Peninsula, Russia. Water, Air, Soil, Poll. 149:339-361.

Weckström J, Korhola A, Erästö P, Holmström L, 2006. Temperature patterns over the past eight centuries in northern Fennoscandia inferred from sedimentary diatoms. Quaternary Res. 66:78-86.

Wetzel RG, 2001. Limnology. Lake and river ecosystems. 3rd ed. Academic Press: 1006 pp.

Wilkinson AN, Zeeb BA, Smol JP, 2001. Atlas of Chrysophycean Cysts. Volume II. Kluwer Academic Publishers, Dordrecht: $169 \mathrm{pp}$.

Wolfe AP, Kling HJ, 2001. A consideration of some North American soft-water Brachysira taxa and description of B. arctoborealis sp. nov., p. 243-264. In: R. Jahn, J.P. Kociolek, A. Witkowski and P. Compere (eds.), Lange-BertalotFestschrift Studies on diatoms. Gantner, Ruggell. 